Deneysel Araştırma / Experimental Research

\title{
MCF-7 meme kanseri hücre hattında doksorubisin ve monensinin hücre çoğalması ve sağ kalım ile ilişkili gen ifadelenme düzeyleri üzerine etkisi
}

\author{
The effects of monensin and doxorubicin on cell survival and gene expressions in MCF-7 cell line
}

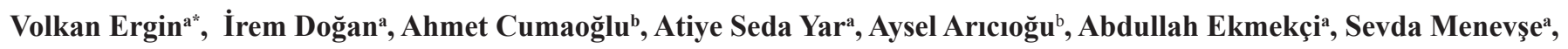
Adnan Menevşe ${ }^{a}$

${ }^{a}$ Gazi Üniversitesi Tip Fakültesi, Tıbbi Biyoloji ve Genetik Anabilim Dalı, Ankara

${ }^{b}$ Gazi Üniversitesi Tıp Fakültesi, Tıbbi Biyokimya Anabilim Dalı, Ankara

\begin{tabular}{|c|c|}
\hline МАKA & GÍLERİ \\
\hline Makal & \\
\hline Geliş & 11 / 03 / 2011 \\
\hline Kabul & 22 / 03 / 2011 \\
\hline * Yazış & esi: \\
\hline Volkan & \\
\hline Gazi Ü & si Tıp Fakültesi \\
\hline Tibbi B & e Genetik Anabilim Dalı \\
\hline Beşevl & \\
\hline e-posta & rgin@gmail.com \\
\hline
\end{tabular}

\section{Anahtar Kelimeler:}

Monensin

Doksorubisin

MCF-7

Apoptozis

MTT

Real-time PCR

\section{Keywords:}

Monensin

Doxorubicin

MCF-7

Apoptosis

MTT

Real-time PCR

\section{ÖZET}

Bu çalışmada doksorubisin ve monensinin tek ve birlikte kullanımlarının, meme kanseri hücre hattı MCF-7 üzerinde hücre çoğalması ile anti-apoptotik ve pro-apoptotik genlerin ifadelenme düzeylerine etkilerini araştırmayı amaçladık. Çalışmamızda MCF-7 hücreleri 24 saat süreyle monensin ve doksorubisinin çeşitli konsantrasyonlarına maruz bırakı1d1. Tedavi uygulanan gruplarda ve kontrol gruplarında, nükleer faktör-kappa B (NF-kB), survivin, BCL2, mTOR ve kaspaz 3 (CASP3) gen ifadeleri mRNA düzeyinde araştırıldı. Tek başına monensin ve tek başına doksorubisin kullanımları NF-kB, survivin, BCL2, mTOR genlerinin ifadelenme düzeylerini azaltırken, CASP3 ifadelenmesi üzerinde etki göstermediği belirlendi. Her iki maddenin birlikte kullanımının BCL2 mRNA düzeyini azalttığı gözlendi. Sonuç olarak, doksorubisin ve monensinin ayrı kullanımlarının hücre ölümü üzerinde etkili oldugu, birlikte kullanıldıklarında ise, sinerjik etki yaparak tek başına kullanımlarında ölçülen IC $_{50}$ dozunu ve anti-apoptotik BCL2 mRNA düzeyini önemli derece azalttığı belirlendi.

J. Exp. Clin. Med., 2011; 28:59-63

\begin{abstract}
The aim of this study is to investigate the proliferative and anti/pro-apoptotic effects of monensin and doxorubicin alone as well as with their combination on MCF-7 breast cancer cells. MCF-7 cells were treated with various concentrations of monensin and doxorubicin for 24 hours. The expression levels of Nuclear Factor-kappa B (NF-kB), survivin, $\mathrm{BCL} 2$, mTOR, and caspase 3 (CASP3) genes were analyzed in treated and control groups at transcriptional level. The expression levels of NF-kB, survivin, BCL2, mTOR were decreased in doxorubicin and monensin treated cells, CASP3 mRNA levels were similar within both groups. Combination of doxorubicin and monensin decreased BCL2 mRNA levels. In conclusion, doxorubicin or monensin was individually effective on inhibition of cell death. Combination of these compounds caused a significant decrease in IC50 dose of doxorubicin and monensin treatment and also decreased anti-apoptotic gene BCL2 mRNA levels.

J. Exp. Clin. Med., 2011; 28:59-63
\end{abstract}

(C) 2011 OMU All rights reserved

\section{Giriş}

En sık karşılaşılan kanser tiplerinden biri olan meme kanseri, dünyada kadınlar arasında \%10,4'lük sıklıkla üçüncü sırada yer almaktadır (World Cancer Report, 2003). Hastalığın tedavisinde cerrahi, radyasyon tedavisi, endokrin tedavi ve/ veya kemoterapi uygulanmaktadır (De Laurentiis ve ark., 2010). Kemoterapide siklikla doksorubisin, siklofosfamid, metotreksat ve florourasil gibi ilaçlar kullanılmaktadır (Muss ve ark., 2009). Meme kanseri tedavisinde en s1k kullanılan ilaçlardan biri olan doksorubisin, DNA'ya interkalasyon yaparak topoizomeraz II enzimini baskılayıp replikasyona engel olmaktadır. Bu durumda hücre döngüsü durdurularak hücre apoptozise yönlendirilmektedir (Momparler ve ark., 1976). Ancak çeşitli meme kanseri olgularında doksorubisin gibi anti-kanser ajanlara direnç geliştiği bilinmektedir. Monensin, Streptomyces cinnamonensin türünden elde edilen karbok- 
sil polieter yapıda bir iyonofordur. Biyolojik zarlardan $\mathrm{Na}^{+}$/ $\mathrm{H}^{+}$antiportu sağlayarak hücrede etkili olmaktadır. $\mathrm{Na}^{+}, \mathrm{K}^{+}$, $\mathrm{Li}^{+}, \mathrm{H}^{+}$gibi monovalent katyonlar ile lipofilik bir kompleks oluşturan monensin, katyonların hücre zarından kolaylıkla geçmelerini sağlayarak, hücre içi ve hücre dişı katyon derişimlerinde düzensizlik oluşturup çeşitli biyokimyasal ve histolojik değişimlere neden olmaktadır (Mollenhauer ve ark., 1990). Hücre dışındaki konsantrasyonu aktif taşıma ile yüksek seviyede tutulan $\mathrm{Na}^{+}$, monensin aracılığıyla hücre içerisine alınmaktadır. Bununla birlikte hücre içerisindeki protonlar da yine aynı yolla hücre dışına çıkarılmaktadır. Hücre içi pH'nın artması ile birlikte, alınan $\mathrm{Na}^{+}$iyonları $\mathrm{Na}^{+} / \mathrm{Ca}^{++}$ antiportunu sağlayan pompa aracılığıyla tekrar hücre dışına çıkarılmakta fakat bu defa hücreye $\mathrm{Ca}^{++}$girişi olmaktadır. Bu iyonik değişim hücrenin hacmini, asit-baz ve osmotik dengesini, organel yapılarını etkilemektedir (Rotin ve Grinstein, 1989). Monensin hücreye, iyon dengesini değiştirerek $\mathrm{Ca}^{++}$yüklenmesi, lipid peroksidasyonu, plazma, endoplazmik retikulum, golgi ve mitokondri membran bütünlüğünün bozulması şeklinde etki etmektedir (Bergen ve Bates, 1984). Monensin çeşitli kanser hücre hatlarında apoptozisi başlatarak hücre ölümüne neden olmaktadır (Park ve ark., 2003; Ketola ve ark., 2010). Bununla birlikte bazı çalışmalarda monensinin hücrede apoptozisden çok nekrozis ile hücre ölümlerine neden olduğu vurgulanmaktadır (Souza ve ark., 2005). Hücrenin ölüm sinyalini almasıyla başlatılan, membran tomurcuklanması, kaspaz yolağının aktivasyonu ve DNA fragmentasyonu ile karakterize edilen programlanmış hücre ölümü olan apoptozis genetik kontrol altında fizyolojik bir olgudur. Apoptozis üzerindeki genetik kontrol, apoptozisi indükleyen pro-apoptotik gen ürünleri ve apoptozisi baskılayan anti-apoptotik gen ürünlerinin dengesi ile sağlanmaktadır (Niu ve Chen, 2010). Çalışmamızda doksorubisin, monensin ve kombinasyonlarının, MCF-7 meme kanseri hücre hattında, hücre proliferasyonu ve nükleer faktör-kappa B (NF- $\mathrm{B})$, survivin, BCL2, mTOR, kaspaz 3 (CASP3) gibi apoptotik ve anti-apoptotik genlerin transkripsiyon düzeyinde ifadelenmeleri üzerine etkileri araştırılmıştır.

\section{Araştırma Yöntemi}

Çalışmamızda meme kanseri hücre hattı MCF-7 (American Type Culture Collection, ATCC, ABD) kullanılmıştır. Hücreler $\% 5 \mathrm{CO}_{2}$ içeren ve $37^{\circ} \mathrm{C}$ sıcaklıkta Dulbecco's Modified Eagle's Medium (DMEM, HyClone, ABD) kullanılarak kültüre edildi. DMEM, ısı ile inaktifleştirilmiş \%10 fetal sığır serum (FBS, HyClone, ABD), $100 \mathrm{U} / \mathrm{mL}$ penisilin, $100 \mu \mathrm{g} /$ $\mathrm{mL}$ streptomisin, $2 \mathrm{mM}$ L-glutamin (HyClone, ABD) içermektedir. Doksorubisin (Doxorubicin $\mathrm{HCl}$, Tocris Bioscience, GB), kalsiyum ve magnezyum içermeyen $50 \mathrm{mM}$ fosfat tamponu PBS (HyClone, ABD) içerisinde çözdürüldü. Monensin (Sigma, ABD) ise metanol içerisinde çözdürüldü. PBS ve metanolün olası yan etkilerini kontrol etmek için sitotoksisite deneyinde negatif kontrol olarak kullanıldı. Doksorubisin $(0-128 \mu \mathrm{mol} / \mathrm{L})$, monensin $(0-50 \mu \mathrm{mol} / \mathrm{L})$ ve doksorubisin ile monensinin çeşitli kombinasyonlarının hücre proliferasyonu üzerindeki etkileri MTT [3-(4,5-dimethylthiazol-2yl)-2,5-diphenyl tetrazolium bromide] (Cayman Chemical, ABD) deneyi ile gösterildi. MTT deneyi için 96 kuyucuklu hücre kültür plate'inin her bir kuyucuğuna $1 \times 10^{4}$ hücre $(n=3)$ ekildi ve 24 saat hücrelerin kültür plate'i zeminine tutunması için beklendi. Daha sonra istenen konsantrasyon- daki $200 \mu \mathrm{L}$ doksorubisin, monensin ve kombinasyonları her bir kuyucuğa dağıtıldı ve 24 saat ilaca maruz birakıldı. Belirtilen inkübasyon zamanından sonraki tedaviyi takiben her kuyucuğa $10 \mu \mathrm{L}$ MTT solusyonu $(5 \mathrm{mg} / \mathrm{mL})$ eklendi ve plate'ler $37^{\circ} \mathrm{C}$ 'de 4 saat inkübe edildi. Kuyucuklardaki reaksiyona girmeyen MTT solusyonu çıkarıldı ve $100 \mu \mathrm{L}$ asidifiye sodyum dodesil sülfat (\% $10 \mathrm{SDS}, 0,01 \mathrm{M} \mathrm{HCl}$ içerisinde) kuyucuklara eklendi ve formazan kristalleri eriyene kadar karıştırıldı. Her kuyucuğun absorbans değeri $570 \mathrm{~nm}$ dalga boyunda mikroplate okuyucu (Molecular Devices, ABD) ile belirlendi. Apoptozis ve sağ kalım ile ilişkili genlerin hücre içi mRNA ifadelenmelerini ölçmek için, total RNA izolasyonu (RNAzol, MRC, ABD) yapıldı. MCF-7 hücreleri 25 $\mathrm{cm}^{2}$ 'lik hücre kültür flaskına ekilerek, $37^{\circ} \mathrm{C}$ ' de inkübe edildi. Flaskın tabanı \%70-80 doluluğa ulaştığında, besiyeri yenilenerek hücreler toksik doksorubisin $(8 \mu \mathrm{mol} / \mathrm{L})$, toksik monensin $(10 \mu \mathrm{mol} / \mathrm{L})$ ve monensin/doksorubisin kombinasyonu $(1 \mu \mathrm{mol} / \mathrm{L}+1 \mu \mathrm{mol} / \mathrm{L})$ ile 6 saat muamele edildi. Elde edilen total RNA'nın saflığı ve miktarı spektrofotometre (NanoDrop, Thermo Scientific, ABD) ile ölçüldü. Total RNA'dan 1 $\mu \mathrm{g}$ alınıp, rastgele (random) hegzamerler kullanılarak toplam hacim $12 \mu \mathrm{L}$ olacak şekilde, ilk zincir (first strand) cDNA Sentez Kiti (Roche Applied Science, Almanya) yardımıyla cDNA sentezi yapıldı. Daha sonra genlerin mRNA ifadelenme düzeylerini ölçmek için, $2 \mu \mathrm{l}$ cDNA, $0,5 \mu \mathrm{l}$ ileri ve geri primerler (GAPDH F:5'-GCTCTCTGCTCCTCCTGTTC-3' R:5'-ACGACCAAATCCGTTGACTC-3', NF ${ }_{K} \mathrm{~B}$ F:5'-CTGGCAGCTCTTCTCAAAGC-3' R:5'-TCCAGGTCATAGAGAGGCTCA-3' , survivin F:5'-CACCGCATCTCTACATTCAAGA-3' R:5'-CAAGTCTGGCTCGTTCTCAGT-3', BCL2 F:5'-TACCTGAACCGGCACCTG-3' R:5'-GCCGTACAGTTCCACAAAGG-3', mTOR F:5'-AGTGAATCTGTGCCATCGAGT-3' R:5'-AGTAGAGCTGCTGCCAAACC-3', CASP3 F:5'-GTGGAATTGATGCGTGATGT-3' R:5'-ACAGGTCCATTTGTTCCAAAA-3'), 0,2 $\mu$ l prob (prob numaralar1 sirasiyla: GAPDH \#60, NF- $\mathrm{B} \# 22$, survivin \#86, BCL2 \#75, mTOR \#88, CASP3 \#68, Universal Probe Library, Roche Applied Science, Almanya), 2,5 $\mu \mathrm{l}$ TaqMan master karışım (Roche Applied Science, Almanya), $1,2 \mu \mathrm{MgCl} 2$ ve toplam hacim $10 \mu \mathrm{l}$ olacak şekilde saf su karıştırılarak Real-time PCR reaktanları hazırlandı. Realtime PCR cihazinda (LC480, Roche Applied Science, Almanya) $95{ }^{\circ} \mathrm{C} 10$ dakikalık ön inkübasyonu, 55 tekrarl $195^{\circ} \mathrm{C} 10$ saniye, $60^{\circ} \mathrm{C} 20$ saniye, $60^{\circ} \mathrm{C} 1$ saniyelik annealing döngüsü sonucu elde edilen $\mathrm{Ct}$ değerleri kaydedildi. MTT deney sonuçları (Ortalama \pm Standart Hata), SigmaStat (v. 3.5) istatistik programında gruplar arası karşılaştırma Student's t kullanılarak gerçekleştirildi. $\mathrm{p}<0,05$ anlamlı kabul edildi. NF${ }_{k} \mathrm{~B}$, survivin, BCL2, mTOR, kaspaz 3 mRNA ifadelenmeleri GAPDH mRNA düzeyine göre normalize edildikten sonra göreceli değişimleri REST (Relative expression software tool) analizi ile değerlendirildi.

\section{Sonuçlar}

Monensin ve doksorubisinin MCF-7 hücre çoğalması üzerinde engelleyici etkilerinin olduğu gözlendi. MCF-7 hücre hattında, 24 saat tedavi sonrası letal doz $\left(\mathrm{IC}_{50}\right)$ değerleri doksorubisin için $8 \mu \mathrm{M}$ (Şek. 1), monensin için $10 \mu \mathrm{M}$ (Şek. 2) olarak ölçüldü. Toksik olmayan $1 \mu \mathrm{M}$ doksorubisin ve $1 \mu \mathrm{M}$ monensin kombinasyonlarının (Şek. 3) 24 saat tedavi sonrası 
MCF-7 hücrelerinde, hücre çoğalması üzerinde etkin bir inhibisyon gösterdiği belirlendi. Anti-apoptotik survivin, BCL2, mTOR genlerinin hücre içi mRNA düzeyleri toksik monensin, toksik doksorubisin tedavilerinde istatistiksel olarak anlamlı derecede azalırken, CASP3 düzeylerinde anlamlı değişim gözlenmedi. Bununla birlikte BCL2 ve survivin genlerinin transkripsiyonunun düzenlenmesinde etkin bir transkripsiyon faktörü olan NF-KB'nin hücre içi mRNA ifadelenmesi toksik monensin ve toksik doksorubisin uygulaması ile istatistiksel açıdan anlamlı derecede azaldı. Doksorubisin ve monensin kombinasyonu BCL2 mRNA düzeyini anlamlı derecede azaltt1. Aynı kombine tedavi hücrelerde mTOR, survivin, NF${ }_{K} \mathrm{~B}$ mRNA düzeylerinde istatistiksel olarak anlamlı değişime neden olmazken, CASP3 düzeyini artırd1, fakat bu artış istatistiksel olarak anlamlı değildi. Genlerin ölçülen mRNA düzeyleri Şekil 4'de gösterilmektedir.

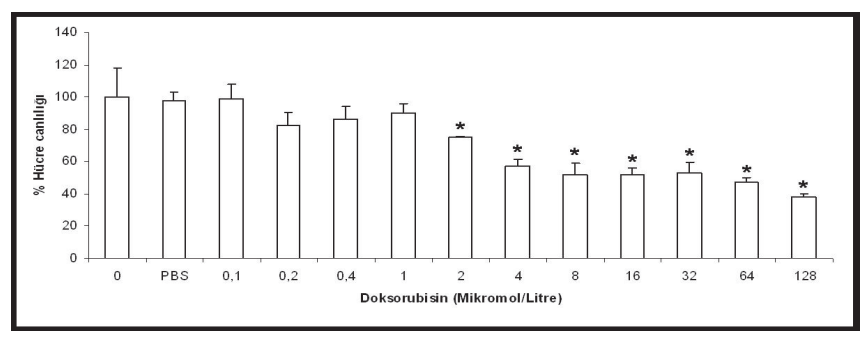

Şek. 1. MCF-7 hücre hattında doksorubisinin 24 saat inkübasyon sonrası hücre canlılığı üzerine etkisi. $\mathrm{n}=3, * \mathrm{p}<0,05$ vs. Kontrol grubu hücreler.

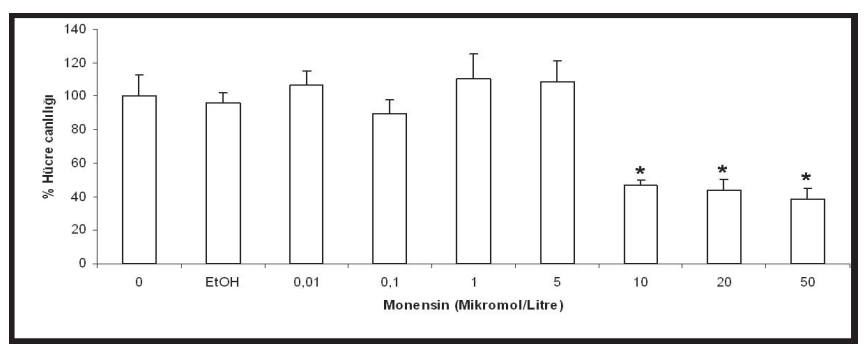

Şek. 2. MCF-7 hücre hattında monensinin 24 saat inkübasyon sonrası hücre canlılığ 1 üzerine etkisi. $n=3, * p<0,05$ vs. Kontrol grubu hücreler.

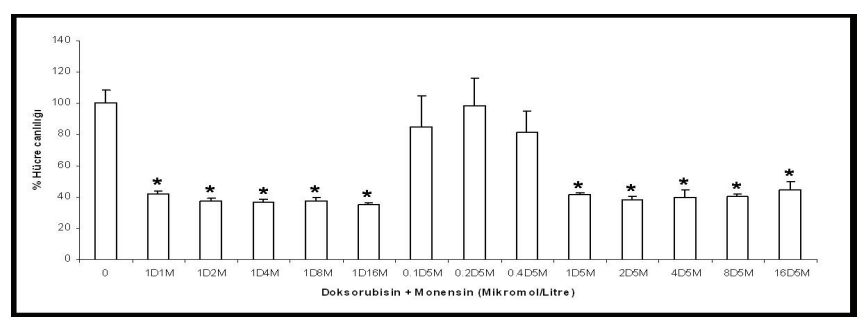

Şek. 3. MCF-7 hücre hattında doksorubisin ve monensin kombinasyonlarının 24 saat inkübasyon sonras1 hücre canlılığı üzerine etkisi. D: Doksorubisin, M: Monensin, $n=3,{ }^{*} p<0.05$ vs. Kontrol grubu hücreler.

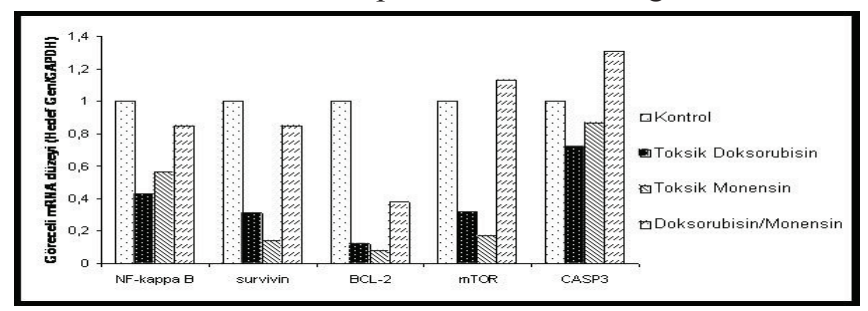

Şek. 4. Doksorubisin, monensin ve kombinasyonlarının anti-apoptotik ve pro-apoptotik genlerin mRNA ifadelenme düzeyleri üzerine etkisi. Toksik doksorubisin $8 \mu \mathrm{mol} / \mathrm{L}$, toksik monensin $10 \mu \mathrm{mol} / \mathrm{L}$, Doksorubisin/Monensin kombinasyonu $1 \mu \mathrm{mol} / \mathrm{L}+$ $1 \mu \mathrm{mol} / \mathrm{L}$.

\section{Tartışma}

Yapılan birçok çalışma göstermiştir ki, kemoterapinin önündeki en önemli engellerden biri kanser hücrelerinin apoptozise karşı geliştirdiği dirençtir. Bu kapsamda güncel yaklaşımlardan biri kanser hücrelerinin kemoterapiye hassasiyet kazanması ve direncin kırılması için anti-kanser ilaçlar ile birlikte çeşitli ilaçların kullanılması yönündedir. Bu bağlamda monensinin birçok kanser hücre hattı üzerinde ilaç direncini azalttı̆̆ gösterilmiştir (Sehested ve ark., 1988). Biz de çalışmamızda klinikte kanser hastalarının tedavisinde sıkça kullanılan bir kemoterapötik olan doksorubisin'in tek başına ve bir iyonofor olan monensinle kombinasyonunun hücre proliferasyonu ve apoptozisle ilişkili genler üzerine etkisini gösterdik. Doksorobisin ( $\mathrm{IC}_{50}: 8 \mu \mathrm{mol} / \mathrm{L}$ ) ve monensin $\left(\mathrm{IC}_{50}: 10\right.$ $\mu \mathrm{mol} / \mathrm{L})$ tek başına kullanıldıklarında $\mathrm{MCF}-7$ hücre hattında hücre ölümünü anlamlı derece de artırdı. Daha önce yapılan birçok çalışmada monensinin tümör hücre hatlarında hücre proliferasyonunu durdurucu etkisi vurgulanmıştır. Monensin $(10 \mu \mathrm{M})$, ilaç direnci olan tümör hücre hatlarında, antrasiklin grubu kemoteröpatiklerin hücre içersine alınımını artırmıştır (Wood ve ark., 1996; Cleary ve ark., 1997). Ayrıca Singh ve arkadaşları lipozomla paketlenmiş monensin uygulamasının doksorubisine dirençli myeloblastik lösemi hücrelerinde doksorubisin alınımını artırdığını ve doksorubisinin hücre dışına geçişini engellediğini göstermişlerdir (Singh ve ark., 1999). Yine Shaik ve arkadaşları çalışmalarında monensinle birlikle doksorubisin kombinasyonunun doksorubisine dirençli MCF-7 meme kanseri hücre hattında hücre içi doksorubisin birikimini artırdığını belirtmişlerdir. Aynı çalışmada doksorubisin ve monensin kombinasyonunun kemoterapiye dirençte etkin rol oynayan hücre zarı kaset proteinlerinden MDR1 ve MRP1 genlerinin mRNA ifadelenme düzeylerini anlamlı derecede azaltarak, kanser hücrelerinin kemoterapiye hassasiyetini artırdığı gösterilmiştir (Shaik ve ark., 2004). Bizim çalışmamızda ise doksorubisin ve monensinin sitotoksik olmayan konsantrasyonlarının kombinasyonu $(1 \mu \mathrm{mol} / \mathrm{L}$ Doksorubisin $+1 \mu \mathrm{mol} / \mathrm{L}$ Monensin) hücre canlılığını anlamlı derecede azalttı. Çalışmamızın sonuçlarına benzer olarak paklitaksel $\left(\mathrm{IC}_{50}: 4,2 \mu \mathrm{g} / \mathrm{mL}\right)$ ve etopozid $\left(\mathrm{IC}_{50}: 61 \mu \mathrm{g}\right.$ / $\mathrm{mL}$ ) doksorubisin dirençli MCF-7 üzerinde sitotoksik etki göstermiştir. $\mathrm{Bu}$ ilaçların tek başına kullanımlarına kıyasla 20 x 10-8 mol/L monensinle kombinasyonları (Paklitaksel/ monensin için $\mathrm{IC}_{50}: 1,5 \mu \mathrm{g} / \mathrm{mL}$, Etopozit için $\mathrm{IC}_{50}: 10,9 \mu \mathrm{g} /$ $\mathrm{mL}$ ), ilaçların etkin doz konsantrasyonlarını daha düşük seviyelere çekmiştir (Shaik ve ark., 2004). Apoptozis, iyonize radyasyon ve anti-kanser kemoterapötik ilaçlar gibi çeşitli ajanlara yanıt olarak hücrelerde gelişen kontrollü bir hücresel ölüm mekanizmasıdır. Apoptozis Bax, Bad, BclXS ve pro-kaspazlar olmak üzere çeşitli pro-apoptotik proteinler ve Bcl2, BclXL, survivin gibi anti-apoptotik proteinler arasındaki denge ile düzenlenmektedir. Özellikle aktive olmuş kaspaz-3 hücrede poli(ADP riboz) polimeraz gibi bir çok proteinin yıkımını sağlayarak, apoptotik süreçte anahtar molekül olarak rol oynamaktadır (Riedl ve Shi, 2004; Elmore, 2007). Monensinin SNU-C1 kolon kanseri hücre 
hattında siklin-bağımlı kinaz 2 (CDK2), siklin-bağımlı kinaz 4 (CDK4), siklin-bağımlı kinaz 6 (CDK6), Siklin D1, Siklin A gibi hücre döngüsünde etkin proteinlerin ifadelenmelerini azalttığı ve sonucunda hücre bölünmesini durdurarak, apoptozisi uyardığı gösterilmiştir. Aynı çalışmada monensin Bax, kaspaz-3 gibi pro-apoptotik proteinlerin ifadelenmesini artırıp, mitokondri membran potansiyelini düşürerek apoptozise yol açmıştır (Park ve ark., 2003a). Aynı çalışma grubu monensinin böbrek kanseri hücre hattında (Caki-2), hücre döngüsünde görevli CDK2, CDK6, cdc2, Siklin A, Siklin B1 gibi proteinlerin ifadelenmelerini azaltıp, p21 ve p27 proteinlerinin ifadelenmelerini artırarak hücre döngüsünü G1/G2-M evrelerinde durdurduğunu göstermiştir. Bu durum aynı hücre hattında apoptozisin belirteci Bcl-2, BclXL, kaspaz 3, kaspaz 7, kaspaz 9 gibi bazı proteinlerin ifadelenmesinde ve mitokondri membran potansiyelinde değişimlere neden olmuştur. Böylece monensin hücre bölünmesini, hücre döngüsünü durdurarak ya da apoptozisi aktive ederek engellemektedir (Park ve ark., 2003b). On farklı akut myelositik lösemi hücre hattında monensinin düşük konsantrasyonlarda (yaklaşık $\left.\mathrm{IC}_{50}: 0,5 \mu \mathrm{M}\right)$ anti-proliferatif etki gösterdiği vurgulanmıştır. Aynı çalışmada monensin ile tedavi edilen HL-60 hücrelerinde apoptozisin belirteci Bax proteinleri artmış, apoptozise dirençte etkili Bcl2 proteininin ifadelenmesi azalmıştır. Bununla birlikte aynı hücre hattında monensin tedavisi mitokon- dri membran potansiyelini düşürmüştür (Park ve ark., 2002). Bizde MCF-7 meme kanseri hücre hattında apoptozise dirençte etkili olan survivin ve Bcl2'nin tek başına monensin ve doksorubisin tedavileri sonrası ifadelenmelerinin azaldığını gösterdik. Bununla birlikte monensin ve doksorubisin inflamasyon, immünite, hücre proliferasyonu ve apoptozis gibi süreçlerde merkezi bir rol oynayan transkripsiyon faktörü $\mathrm{NF}-k \mathrm{~B}$ 'nin gen ifadelenmesini azaltt1. NF- $\mathrm{KB}^{\mathrm{B}}$ nin inhibisyonu ile survivin ve BCL2 gibi genlerin ifadelenmelerinde azalma olduğu daha önceki çeşitli çalışmalarda gösterilmiştir (Tracey ve ark., 2005). Kanser gelişim sürecinde proliferasyonu pozitif yönde düzenlediği bilinen bir diğer gen ürünü olan mTOR'un inhibisyonunun, kanser tedavisinde etkin bir hedef olabileceği çeşitli çalışmalarda gösterilmiştir (Easton ve Houghton, 2006; Faivre ve ark., 2006; Yecies ve Manning, 2011). Bizim çalıșmamızda monensin ve doksorubisin uygulamas1, meme kanseri hücre hattında mTOR gen ifadelenme düzeylerini anlamlı derecede azalttı. Doksorubisin ve monensinin birlikte kullanımları sonucu BCL2 gen ifadelenmesi azalırken, kaspaz 3 gen ifadelenmesi arttı. Sonuç olarak doksorubisin ve monensinin tek başına kullanımlarında toksik olmayan dozlarının, bu iki ilacın kombinasyonu sonucu hücre proliferasyonunu baskıladığı, apoptozise direnci azalttığı ve apoptozise yatkınlığı artırdığı gösterilmiştir.

\section{KAYNAKLAR}

Bergen, W.G., Bates, D.B., 1984. Ionophores: their effect on production efficiency and mode of action. J. Anim Sci. 58, $1465-1483$.

Cleary, I., Doherty, G., Moran, E., Clynes, M., 1997. The multidrug-resistant human lung tumour cell line, DLKP-A10, expresses novel drug accumulation and sequestration systems. Biochem. Pharmacol. 53, 1493-1502.

De Laurentiis, M., Cianniello, D., Caputo, R., Stanzione, B., Arpino, G., Cinieri, S., Lorusso, V., De Placido, S., 2010. Treatment of triple negative breast cancer (TNBC): current options and future perspectives. Cancer Treat Rev. 36, 80-86.

Easton, J.B., Houghton, P.J., 2006. mTOR and cancer therapy. Oncogene. 25, 6436-6446.

Elmore, S., 2007. Apoptosis: a review of programmed cell death. Toxicol Pathol. 35, 495-516.

Faivre, S., Kroemer, G., Raymond, E., 2006. Current development of mTOR inhibitors as anticancer agents. Nat. Rev. Drug Discov. 5, 671688.

Ketola, K., Vainio, P., Fey, V., Kallioniemi, O., Iljin, K., 2010. Monensin is a potent inducer of oxidative stress and inhibitor of androgen signaling leading to apoptosis in prostate cancer cells. Mol. Cancer Ther. 9, 3175-3185.

Mollenhauer, H.H., Morré, D.J., Rowe, L.D., 1990. Alteration of intracellular traffic by monensin; mechanism, specificity and relationship to toxicity. Biochim Biophys Acta. 1031, 225-246.

Momparler, R.L., Karon, M., Siegel, S.E., Avila, F., 1976. Effect of adriamycin on DNA, RNA, and protein synthesis in cell-free systems and intact cells. Cancer Res. 36, 2891-2895

Muss, H.B., Berry, D.A., Cirrincione, C.T., Theodoulou, M., Mauer, A.M., Kornblith, A.B., Partridge, A.H., Dressler, L.G., Cohen, H.J., Becker, H.P., Kartcheske, P.A., Wheeler, J.D., Perez, E.A., Wolff, A.C., Gralow, J.R., Burstein, H.J., Mahmood, A.A., Magrinat, G., Parker, B.A., Hart, R.D., Grenier, D., Norton, L., Hudis, C.A., Winer, E.P.; CALGB Investigators., 2009. Adjuvant chemotherapy in older women with early-stage breast cancer. N. Engl. J. Med. 360, 2055-2065.

Niu, G., Chen, X., 2010. Apoptosis imaging: beyond annexin V. J. Nucl. Med. 51, 1659-1662.

Park, W.H., Jung, C.W., Park, J.O., Kim, K., Kim, W.S., Im, Y.H., Lee, M.H., Kang, W.K., Park, K., 2003b. Monensin inhibits the growth of renal cell carcinoma cells via cell cycle arrest or apoptosis. Int. J. Oncol. 22, 855-860.

Park, W.H., Kim, E.S., Jung, C.W., Kim, B.K., Lee, Y.Y., 2003a. Monensin-mediated growth inhibition of SNU-C1 colon cancer cells via cell cycle arrest and apoptosis. Int. J. Oncol. 22, 377-382

Park, W.H., Kim, E.S., Kim, B.K., Lee, Y.Y., 2003. Monensin-mediated growth inhibition in NCI-H929 myeloma cells via cell cycle arrest and apoptosis. Int. J. Oncol. 23, 197-204

Park, W.H., Lee, M.S., Park, K., Kim, E.S., Kim, B.K., Lee, Y.Y., 2002. Monensin-mediated growth inhibition in acute myelogenous leukemia cells via cell cycle arrest and apoptosis. Int. J. Cancer. 101, 235-242.

Riedl, S.J., Shi, Y., 2004. Molecular mechanisms of caspase regulation during apoptosis. Nat. Rev. Mol. Cell Biol. 5, 897-907.

Rotin, D., Grinstein, S., 1989. Impaired cell volume regulation in $\mathrm{Na}(+)-\mathrm{H}+$ exchange-deficient mutants. Am. J. Physiol. $257,1158-1165$.

Sehested, M., Skovsgaard, T., Roed, H., 1988. The carboxylic ionophore monensin inhibits active drug efflux and modulates in vitro resistance in daunorubicin resistant Ehrlich ascites tumor cells. Biochem Pharmacol. 37, 3305-3310.

Shaik, M.S., Chatterjee, A., Singh, M., 2004. Effects of monensin liposomes on the cytotoxicity, apoptosis and expression of multidrug resistance genes in doxorubicin-resistant human breast tumour (MCF7/dox) cell-line. J. Pharm. Pharmacol. 6, 899-907.

Singh, M., Ferdous, A.J., Jackson, T.L., 1999. Stealth monensin liposomes as a potentiator of adriamycin in cancer treatment. J. Control Release. $59,43-53$.

Souza, A.C., Machado, F.S., Celes, M.R., Faria, G., Rocha, L.B., Silva, J.S., Rossi, M.A., 2005. Mitochondrial damage as an early event of 
monensin-induced cell injury in cultured fibroblasts L929. J. Vet. Med. Physiol. Pathol. Clin. Med. 52, 230-237

Tracey, L., Pérez-Rosado, A., Artiga, M.J., Camacho, F.I., Rodríguez, A., Martínez, N., Ruiz-Ballesteros, E., Mollejo, M., Martinez, B., Cuadros, M., Garcia, J.F., Lawler, M., Piris, M.A., 2005. Expression of the NF-kappaB targets BCL2 and BIRC5/Survivin characterizes small B-cell and aggressive B-cell lymphomas, respectively. J. Pathol. 206, 123-134.

Wood, D.J., Rumsby, M.G., Warr, J.R., 1996. Monensin and verapamil do not alter intracellular localisation of daunorubicin in multidrug resistant human KB cells. Cancer Lett. 108, 41-47.

World Cancer Report, 2003. International Agency for Research on Cancer.

Yecies, J.L., Manning, B.D., 2011. mTOR links oncogenic signaling to tumor cell metabolism. J. Mol. Med. 89, $221-228$. 